\title{
Safety and efficacy of travoprost solution for the treatment of elevated intraocular pressure
}

This article was published in the following Dove Press journal:

Clinical Ophthalmology

10 April 2015

Number of times this article has been viewed

\author{
Luciano Quarantal,* \\ Ivano Rival,* \\ Andreas Katsanos ${ }^{2}$ \\ Irene Floriani ${ }^{3}$ \\ Marco Centofanti ${ }^{4, \dagger}$ \\ Anastasios G P Konstas ${ }^{5}$ \\ 'Centre for the Study of Glaucoma, \\ University of Brescia, Brescia, \\ Italy; ${ }^{2}$ Ophthalmology Department, \\ University of loannina, loannina, \\ Greece; ${ }^{3}$ Laboratory of Clinical \\ Research, IRCCS, Istituto di Ricerche \\ Farmacologiche Mario Negri, Milan, \\ Italy; ${ }^{4}$ DSCMT, University of Tor \\ Vergata, Rome, Italy; ${ }^{5}$ Glaucoma \\ Unit, Ist University Department \\ of Ophthalmology, AHEPA Hospital, \\ Thessaloniki, Greece \\ *These authors contributed equally \\ to this work; ${ }^{\dagger} \mathrm{Dr}$ Centofanti passed \\ away on I March 2015
}

\begin{abstract}
Travoprost is a prostaglandin analogue widely used for reducing intraocular pressure (IOP) in patients affected with glaucoma and ocular hypertension. It exerts its ocular hypotensive effect through the prostaglandin FP receptors, located in the ciliary muscle and the trabecular meshwork. Several studies have shown that topical administration of travoprost induces a mean IOP reduction ranging from $25 \%$ to $32 \%$, and sustained throughout the 24 -hour cycle. When compared with timolol, travoprost is more effective at reducing IOP, while generally no difference has been found in the head-to-head comparison with other prostaglandin analogues. The fixed combination of travoprost and timolol has demonstrated a hypotensive efficacy comparable to the concomitant administration of the two drugs. Recently, a new preservative-free formulation of travoprost $0.004 \%$ has been marketed for reducing tolerability-related problems in subjects affected with ocular surface disease. Low rates of topical and systemic adverse reactions, strong ocular hypotensive efficacy, and once-a-day dosing make travoprost a first-line treatment for patients affected with elevated IOP.
\end{abstract}

Keywords: prostaglandin analogue, glaucoma, ocular hypertension

\section{Introduction}

Glaucoma is the second leading cause of blindness in the world according to the World Health Organization. It is estimated that over 2.2 million Americans are affected by glaucoma, but only half of them are aware of the disease and properly treated. ${ }^{1}$ Studies estimate that the number of patients blind from glaucoma is between 5.2 and 6.7 million all around the world, with higher rates of blindness in developing countries, due to lack of detection and limited treatment options.,

Elevated intraocular pressure (IOP) is a major risk factor for glaucoma. Although glaucoma pathogenesis has not been completely understood, high IOP levels may directly damage axons of ganglion cells and reduce blood support to the optic nerve, resulting in ischemia and neurodegeneration. ${ }^{4}$ Additional factors are probably implicated, such as abnormalities of the ocular blood flow, ${ }^{5-7}$ loss of vascular autoregulation, ${ }^{8,9}$ and genetic predisposition. ${ }^{10}$ However, further research along these directions is needed.

Reduction of IOP is the only proven treatment for glaucoma. The Early Manifest Glaucoma Trial demonstrated that in patients with early disease, the risk of progression decreased by $10 \%$ with each $\mathrm{mmHg}$ IOP reduction from baseline. ${ }^{11}$ These results were recently confirmed by the UK Glaucoma Treatment Study. ${ }^{12}$ Several surgical, laser, and pharmacological options are available for reducing IOP. ${ }^{13}$ However, pharmacological approach remains the mainstay of glaucoma therapy and a valuable option for most glaucoma patients.
Correspondence: Luciano Quaranta DSMC University of Brescia, Viale Europa 9, 25 I 23 Brescia, Italy Tel +39030 3995847

Fax +39030396622

Email luciano.quaranta@unibs.it 
Prostaglandin analogues (PGs) are a relatively new class of anti-glaucoma drugs that exert their ocular hypotensive effect through the prostaglandin FP receptors, located in the ciliary muscle and in the trabecular meshwork. ${ }^{14,15}$ A low rate of topical and systemic adverse reactions, strong hypotensive efficacy, and once-a-day administration contributed to the widespread use of these drugs as first-line therapy in glaucoma. Travoprost, a synthetic PG, was introduced in the market in 2001, after approval by the US Food and Drug Administration (FDA) on March of the same year.

\section{Pharmacology and pharmacokinetics}

Travoprost is a synthetic derivative of naturally occurring PG F $2 \alpha$ (PGF2 $\alpha$ ). Natural PGs, especially of the F series, are relatively polar and hydrophilic, and poorly penetrate cell membranes. ${ }^{16}$ Synthetic esterification in carbon-1 position gives travoprost lipophilic properties, increasing penetration though lipid membranes such as corneal epithelium. ${ }^{17,18}$ During the corneal passage, travoprost isopropyl ester situated in carbon-1 position is hydrolyzed, generating an active free acid (Figure 1). ${ }^{14,15,19}$

Travoprost free acid is a potent agonist of FP receptors, about ten-times more potent than latanoprost. ${ }^{14,19}$ In animal models, it reaches high concentration in anterior tissues of the eye (ie, anterior chamber and ciliary body), while very low concentrations are measurable in vitreous, retina, and choroid. ${ }^{20}$

A drop of travoprost $0.004 \%$ contains $1.2 \mu \mathrm{g}$ of travoprost prodrug. After bilateral administration, travoprost free acid reaches a maximum plasma level of $10^{-10} \mathrm{M}$, which remains constant after 7 days of administration (no accumulation). ${ }^{21}$ Plasma half-life of travoprost acid is approximately 45 minutes and less than $2 \%$ of topical ocular dose is excreted in the urine within 4 hours from administration.

\section{Mechanism of action}

Similar to other PGs, travoprost exerts its ocular hypotensive action mainly by increasing uveoscleral outflow, but some effects on trabecular meshwork may be present as well. ${ }^{22}$ An increase in uveoscleral outflow was demonstrated both in monkeys ${ }^{23}$ and in patients affected by ocular hypertension (OHT) and treated with travoprost. ${ }^{24}$ No effect on aqueous humor production was described.

Immunochemistry studies showed the presence of FP receptors in ciliary body and sclera. ${ }^{25}$ Several mechanisms have been proposed to explain the increase in uveoscleral outflow induced by PGs, such as remodeling of the extracellular matrix; ${ }^{26,27}$ relaxation and modifications of the ciliary muscle shape ${ }^{28,29}$ reorganization of actin and vinculin within muscle cells. ${ }^{30}$

Remodeling of the extracellular matrix within the ciliary body is probably the most studied mechanism of action of PGs. Travoprost stimulates secretion and activation of matrix metalloproteinase (MMP)2 in ciliary muscle cells through protein-kinase $\mathrm{C}$ and extracellular signals, regulated by protein-kinase 1- and protein-kinase 2-dependent pathways. ${ }^{31,32}$ MMP2, together with MMP1 and MMP3, induces dissolution of type I and type III collagen of the extracellular matrix. ${ }^{33}$ Studies on monkeys treated with different types of PGs for 1 year showed an increase in optically empty spaces between ciliary body muscle bundles, partially filled with myelinated nerve fibers. ${ }^{34,35}$ Ultrastructurally, these spaces appeared covered with endothelial cells, at direct contact with microvascular basement membranes. The described structures resemble a lymphatic drainage system, similar to the one described in the choroid. ${ }^{36}$ This reorganization of ciliary body may facilitate aqueous humor drainage from the anterior chamber and cause IOP reduction.

In vitro studies on cultured cells provide strong evidences about an effect of travoprost and other PGs on trabecular meshwork. Similarly to ciliary body, secretion and activation of MMPs initiate degradation of extracellular matrix, regulating outflow facility. MMPs are normally expressed by trabecular meshwork ${ }^{37}$ and control outflow resistance in human organ-cultured anterior segments. ${ }^{38}$ Experiments
A

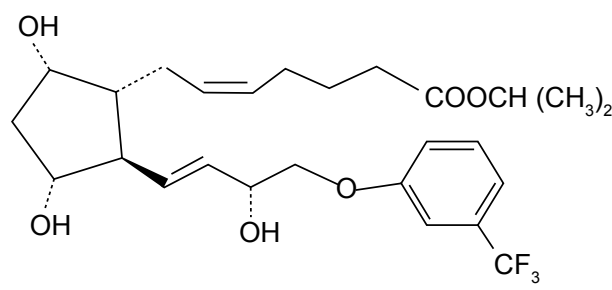

B

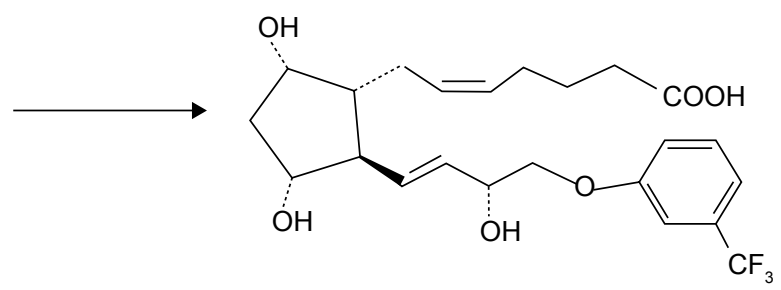

Figure I Travoprost chemical structure.

Notes: (A) Travoprost prodrug. (B) Travoprost free acid, after hydrolysis of isopropyl ester in carbon-I position. 
on pig cultured trabecular meshworks, perfused at constant pressure, showed an increase in outflow facility up to $30 \%$ after intra-cameral injection of PGF $2 \alpha .{ }^{39}$ Histological studies on trabecular meshworks exposed to PGs demonstrated focal regions of endothelial cell loss and endothelial detachment into Schlemm's canal, together with loss of extracellular matrix and consequent reduction of outflow resistance. ${ }^{40}$ Interestingly, a study by Zhao et al showed that prolonged treatment of human trabecular meshwork cells with PGF $2 \alpha$ increases expression of insulin-like growth-factor-1 (IGF-1) and fibroleukin. ${ }^{41}$ IGF-1 is known to stimulate expression of MMPs and the proteinase action of fibroleukin may be active against extracellular matrix, once again remodeling the microstructure of trabecular meshwork and reducing resistance to flow.

\section{Efficacy}

Many studies showed that topical administration of travoprost $0.004 \%$ reduces IOP in patients affected by primary open-angle glaucoma (POAG) and OHT. ${ }^{16,42}$ In an analytic review about the efficacy of PGs in patients affected by POAG, travoprost was found to induce a mean weighted IOP reduction of $28.7 \%{ }^{43}$ Similarly, a meta-analysis by van der Valk et al evaluating randomized clinical trials on most frequently prescribed glaucoma drugs estimated that travoprost is capable of an IOP reduction of between $31 \%$ (peak; 32\%-29\%) and 29\% (trough; 32\%-25\%). ${ }^{44}$

\section{Efficacy: 24-hour studies}

In a short 6-week crossover study, Konstas et al evaluated 24-hour efficacy of travoprost $0.004 \%$ dosed once in the evening versus in the morning. ${ }^{45}$ While there was no difference in mean 24-hour IOP between morning and evening administration $(P=0.7)$, travoprost dosed in the evening achieved a significantly lower 24-hour IOP fluctuation $(3.2 \pm 1.0 \mathrm{mmHg}$ and $4.0 \pm 1.5 \mathrm{mmHg}$, respectively, for evening and morning dosing, $P=0.001)$ and statistically lower IOP at the 10 am time-point $(P=0.02)$. In this study, travoprost was effective in reducing IOP at all daytime and nighttime time-points, sustaining its hypotensive efficacy up to 24 hours after administration. Similarly, in a study comparing 24-hour IOP control with timolol/travoprost fixed combination (FC) versus travoprost alone, ${ }^{46}$ Konstas et al found that travoprost, dosed once in the evening, was effective at reducing IOP during the 24-hour cycle, with a mean 24-hour IOP reduction of $26.3 \%$.

A meta-analysis by Stewart et al investigating the short-term 24-hour efficacy of topical agents in glaucoma ${ }^{47}$

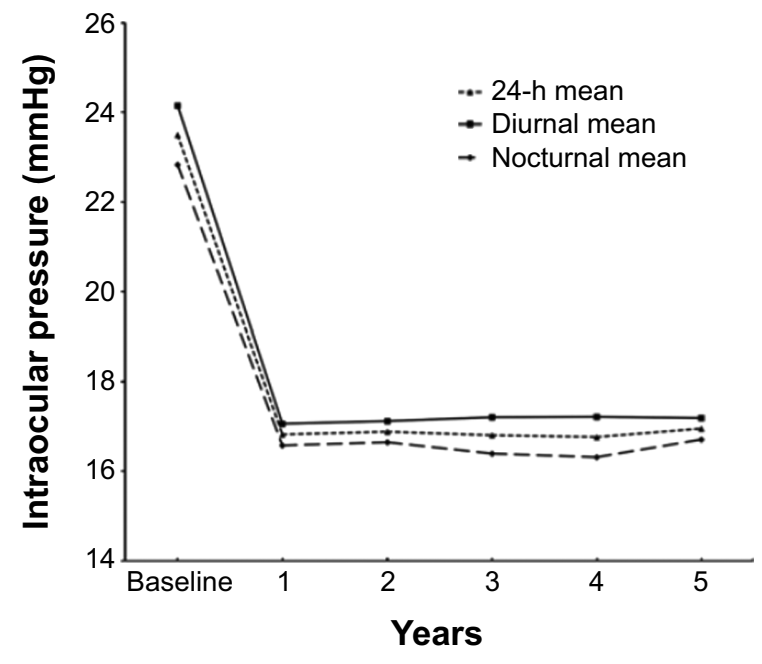

Figure 2 Mean 24-hour, diurnal, and nocturnal intraocular pressure in a cohort of primary open-angle glaucoma patients treated with travoprost monotherapy and followed-up for 5 years.

Note: Reprinted with permission from Riva I, Katsanos A, Floriani I, et al. Longterm 24-hour intraocular pressure control with travoprost monotherapy in patients with primary open-angle glaucoma. J Glaucoma. 20I4;23(8):535-540.49

reported that travoprost reduced mean 24 -hour IOP by $27 \%$ from untreated baseline, with a similar hypotensive effect at diurnal and nocturnal time-points $(P=0.064)$. Similar results were obtained in a small pilot study on patients affected by POAG and OHT by Dubiner et al. They evaluated the persistency of travoprost IOP-lowering efficacy up to 84 hours after the last administration. ${ }^{48}$ Patients were treated in a masked fashion with travoprost $0.004 \%$ in the evening for 2 weeks and then IOP was measured every 4 hours for 36 hours, and 60 and 84 hours after the last dose, with no additional medication. Travoprost induced significant IOP reductions from baseline at all time-points analyzed, up to 84 hours after the last dose $(P<0.001)$. The greatest decrease in IOP was registered at the 8 am timepoint (approximately 12 hours after dosing).

Not many studies investigated 24-hour long-term persistency of travoprost hypotensive efficacy. In a recent study by Riva et al, travoprost $0.004 \%$ given as monotherapy in a cohort of 36 previously untreated POAG patients, induced a quite uniform 24-hour IOP reduction during the 5-year follow-up of the study (range of 24-hour IOP reduction: $27.8 \%-28.6 \%$, Figure 2). ${ }^{49}$ Interestingly, although mean nocturnal IOP reduction with travoprost was somewhat lower than mean daytime IOP reduction, there was no significant difference between nighttime and daytime efficacy $(P>0.05)$.

\section{Comparison with timolol}

Several studies comparing travoprost versus timolol have generally demonstrated a superior IOP control with the 
former. ${ }^{50-54}$ Timolol was considered for a long time as a first-line therapy in glaucoma management, although during the last 2 decades a widespread use of PGs undermined this paradigm. Compared to PGs, initial lower costs of timolol medication are neutralized in the long-term by higher IOPs, more medication changes, greater incidence of glaucoma progression, and less persistency in original therapy. ${ }^{55}$

Goldberg et al randomized 573 patients affected by POAG and OHT to treatment with timolol $0.5 \%$ twice daily or travoprost $(0.004 \%$ and $0.0015 \%)$ dosed once in the evening. ${ }^{50}$ Subjects enrolled had a mean IOP of approximately $26 \mathrm{mmHg}$. The primary efficacy variable was IOP measured at $9 \mathrm{am}, 11 \mathrm{am}$, and $4 \mathrm{pm}$ at baseline and during the 9-month follow-up study visits. Mean diurnal IOP reduction was greater with travoprost $0.004 \%$ (range of IOP reduction: 8-8.9 $\mathrm{mmHg}$ ) than with timolol (range of IOP reduction: $6.3-7.9 \mathrm{mmHg})(P<0.001)$. Interestingly, travoprost $0.004 \%$ reduced IOP significantly more than travoprost $0.0015 \%$ only at the 11 am time-point $(P=0.03)$, the time of peak drug activity.

In a similar 6-month study (ie, same protocol as the previous study) comparing travoprost to timolol, travoprost was superior to timolol in nine of 13 visits with differences in IOP reduction ranging from 0.9 to $1.8 \mathrm{mmHg}(0.0015 \%)$, and in ten of 13 visits with differences in IOP reductions from 0.9 to $2.4 \mathrm{mmHg}(0.004 \%) .{ }^{51}$ The IOP lowering effect of travoprost $0.0015 \%$ and travoprost $0.004 \%$ was similar.

In a study by Netland et al travoprost $(0.004 \%$ and $0.0015 \%$ ) resulted in more effective reduction of diurnal IOP (mean of IOPs at 9 am, 11 am, and 4 pm) than timolol $0.5 \%$ in 801 patients affected by POAG and OHT, with a baseline IOP of approximately $25 \mathrm{mmHg}{ }^{52}$ Mean IOP over visits and time ranged from 17.9 to $19.1 \mathrm{mmHg}$ (travoprost $0.0015 \%$ ), 17.7 to $19.1 \mathrm{mmHg}$ (travoprost $0.004 \%$ ), and 19.4 to $20.3 \mathrm{mmHg}$ (timolol $0.5 \%$ ). Mean IOP in the travoprost $0.004 \%$ group was lower than in the $0.0015 \%$ group at 13 of 18 treatment visits, although this difference was not statistically significant.

A meta-analysis by $\mathrm{Li}$ et al compared travoprost $0.004 \%$ hypotensive efficacy with timolol $0.5 \%$ in patients affected by POAG or OHT. ${ }^{54}$ Four studies were included in this metaanalysis for a total of 1,354 patients. Travoprost $0.004 \%$ resulted in being more effective than timolol $0.5 \%$ in lowering IOP (weighted mean difference $=0.81 \mathrm{mmHg}$ in favor of travoprost, $P<0.001)$.

\section{Comparison with other PGs}

The majority of the studies comparing the efficacy of travoprost against other PGs have shown no significant differences in IOP-lowering ability. ${ }^{52,56-58}$ Similar mechanism of action and comparable effects on uveoscleral outflow and trabecular meshwork are probably at the basis of these results.

Parrish et al compared latanoprost, travoprost, and bimatoprost in a head-to-head randomized 12-week prospective trial, including 410 patients affected by POAG and OHT. ${ }^{56}$ Mean IOP at baseline was similar among the three groups (latanoprost: $25.7 \mathrm{mmHg}$, bimatoprost: $25.7 \mathrm{mmHg}$, and travoprost: $25.5 \mathrm{mmHg}$ ). Adjusted IOP reductions in mean IOP at 8 am were similar $(P=0.12)$, as were those at $12 \mathrm{pm}, 4 \mathrm{pm}$, and $8 \mathrm{pm}$. The estimated 8 am IOP reduction at 12 weeks was $8.6 \pm 0.3 \mathrm{mmHg}$ for latanoprost, $8.7 \pm 0.3 \mathrm{mmHg}$ for bimatoprost, and $8.0 \pm 0.3 \mathrm{mmHg}$ for travoprost (Figure 3 ).

In a 12-month comparison of travoprost with latanoprost, Netland et al found no difference in IOP reduction between the two drugs at the 8 am and 10 am time-points, while travoprost $0.004 \%$ was slightly more effective at the $4 \mathrm{pm}$ time-point $(0.8 \mathrm{mmHg}$ lower with travoprost than latanoprost, pooled data across visits). ${ }^{52}$ Interestingly, travoprost $0.004 \%$ reduced IOP in black patients by up to $2.4 \mathrm{mmHg}$ more than latanoprost.

In 40 patients affected by pseudoexfoliative glaucoma and with a baseline 24-hour IOP of $25.1 \pm 2.5 \mathrm{mmHg}$, Konstas et al found no difference in IOP reduction between latanoprost and travoprost at all diurnal and nocturnal time-points, apart from at the $6 \mathrm{pm}$ assessment, where travoprost provided lower IOP than latanoprost $(16.7 \pm 2.6$ versus $17.9 \pm 2.5 \mathrm{mmHg}$, respectively, for travoprost and latanoprost)..$^{59}$ On the basis of these results, the authors speculated a possible greater hypotensive efficacy of travoprost in the late afternoon; however more studies are needed to confirm these data.

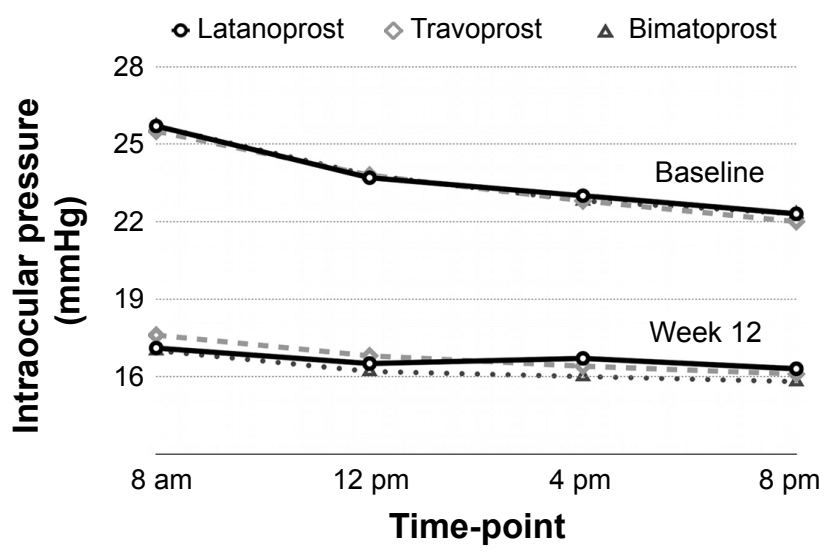

Figure 3 Mean intraocular pressure with latanoprost, travoprost, and bimatoprost at baseline and after 12 weeks of treatment in a cohort of primary open-angle glaucoma and ocular hypertension patients.

Note: Reprinted from Am J Ophthalmol. I 35(5):688-703. Parrish RK, Palmberg P, Sheu WP, XLT Study Group. A comparison of latanoprost, bimatoprost, and travoprost in patients with elevated intraocular pressure: a 12-week, randomized, maskedevaluator multicenter study. Copyright 2003 with permission from Elsevier..$^{56}$ 
Cantor et al randomized 157 patients affected by POAG or OHT to treatment with travoprost $0.004 \%$ or bimatoprost $0.003 \%$, in a double-blind, parallel-group clinical trial. ${ }^{60}$ At the 6-month visit, bimatoprost achieved greater IOP reduction than travoprost at the 9 am time-point $(7.1 \mathrm{mmHg}$ [27.9\%] versus $5.7 \mathrm{mmHg}$ [23.3\%], respectively, for bimatoprost and travoprost), while no significant differences were found between the two drugs at the $1 \mathrm{pm}$ and $4 \mathrm{pm}$ assessment. In this study, patients were more likely to achieve clinically relevant IOP reductions $\geq 20 \%, 25 \%$, or $30 \%$ with bimatoprost than travoprost at the 9 am time-point.

A meta-analysis of published data by $\mathrm{Li}$ et al did not confirm these results and failed to find significant differences in hypotensive efficacy between travoprost and bimatoprost (weighted mean difference: $-0.08 \mathrm{mmHg}$ in favor of bimatoprost, $P=0.8) .{ }^{54}$ However, because baseline IOP values of patients included in the meta-analysis were from 24 to $36 \mathrm{mmHg}$, the results can only be safely assumed in this IOP range.

\section{Travoprost fixed and unfixed combination with timolol}

Approximately $40 \%$ of patients affected by OHT require two or more topical medications to control IOP. ${ }^{61}$ When target IOP is not achieved with a single agent, combined therapy using drugs with different mechanism of action is recommended. An FC of travoprost and timolol allows for reduction of adverse events and increases patients' compliance.

A few studies compared directly the hypotensive efficacy of timolol/travoprost FC against travoprost alone. Barnebey et al randomized 263 patients to travoprost $0.004 \%$ or timolol/ travoprost FC in a 3-month parallel-arm trial. ${ }^{53}$ The primary efficacy variable was mean IOP at $8 \mathrm{am}, 10 \mathrm{am}$, and 4 pm compared with baseline values. Timolol/travoprost FC decreased IOP by $0.9-2.4 \mathrm{mmHg}$ more than travoprost, with a significant differences at seven of the nine study visits $(P<0.05)$.

Konstas et al obtained similar results in a 24-hour crossover study. ${ }^{46}$ Thirty-two POAG and OHT patients were randomized to either timolol/travoprost $\mathrm{FC}$ or travoprost alone for 8 weeks and were then switched to the opposite treatment for another 8 weeks. Assuming a mean baseline 24-hour IOP of $27.7 \mathrm{mmHg}$ (range: $26.7-28.8 \mathrm{mmHg}$ ), timolol/travoprost FC induced a lower absolute IOP level for the 24-hour curve (17.2 $\mathrm{mmHg}$ versus $19.6 \mathrm{mmHg}$, respectively, for timolol/travoprost $\mathrm{FC}$ and travoprost) and at all time-points $(P \leq 0.047)$.

Timolol/travoprost FC was compared to concomitant administration of timolol and travoprost in two studies with similar design. ${ }^{62,63}$ This point is of particular interest, as a recent meta-analysis by Quaranta et al ${ }^{64}$ evaluating overall hypotensive efficacy of $\beta$-blocker/PG FCs showed that concomitant administration is more effective than FC in patients affected by POAG and OHT. These two studies randomized a total of 719 patients to a 3-month treatment with timolol/travoprost FC (administered once in the morning) or concomitant administration of timolol in the morning and travoprost in the evening (once daily both). Patients enrolled had IOP between 22 and $36 \mathrm{mmHg}$ and IOP was assessed at three diurnal time-points (8 am, $10 \mathrm{am}$, and $4 \mathrm{pm})$. Assuming a clinically significant difference between treatments of $1.5 \mathrm{mmHg}$ ( $95.1 \%$ confidence limit), both the studies concluded that timolol/travoprost FC was comparable in efficacy to concomitant administration of timolol and travoprost. Differences in mean diurnal IOP between treatment groups were $\leq 1.5 \mathrm{mmHg}$ at seven of nine visits and at six of nine visits, respectively, in the first ${ }^{62}$ and the second study.$^{63}$ However, a trend toward lower IOP values in the concomitant timolol and travoprost group was evident in both studies. Assuming that timolol in the concomitant medication group was dosed once-a-day and not twice daily, differences in efficacy between the two treatments may reach significance in clinical practice. Further studies are needed to confirm this hypothesis.

\section{Travoprost benzalkonium chloride- free and travoprost $\mathbf{0 . 0 0 3} \%$}

Most anti-glaucoma eye drops have preservatives added to prevent bacterial contamination and allow for long-term use of multidose bottles. Benzalkonium chloride (BAK), a quaternary ammonium detergent, is the most commonly used preservative in ophthalmic drops. ${ }^{65} \mathrm{BAK}$ is known to have cytotoxic side effects on the cornea and conjunctiva, leading to metaplasia and tear film breakdown. ${ }^{66-69}$ The Preservative exposure and surgical outcome study (PESO) demonstrated that increased preoperative exposure to $\mathrm{BAK}$ is a risk factor for glaucoma surgery failure, probably due to the baseline inflammation level and the trend toward higher inflammation response in these eyes. ${ }^{70}$

Travoprost $0.004 \%$ was reformulated in 2010 to replace BAK with polyquaternium-1 (polyquad), a preservative derived from BAK but thought to be gentler on the ocular surface. Despite some studies demonstrating less cell damage and inflammatory infiltration with polyquad-preserved travoprost, ${ }^{71,72}$ recent findings revealed that polyquad itself might have detrimental effects on cell membrane integrity and induce cytotoxicity. ${ }^{73,74}$

A completely preservative-free (PF) travoprost formulation has been marketed in the US since 2006. This formulation 
uses a proprietary preservative system called sofZia (Alcon Laboratories, Inc, Fort Worth, TX, USA), an ionic buffer containing borate, sorbitol, propylene, glycol, and zinc. sofZia chemical components are not significantly toxic to the ocular surface, but are able to maintain an antimicrobial environment. The sofZia system meets the US Pharmacopeia standards for antimicrobial activity. The efficacy and safety of PF travoprost were demonstrated in a multicenter, randomized, parallel-group study among 690 patients diagnosed with POAG and OHT. ${ }^{75}$ Patients were randomized to treatment with BAK-preserved or PF travoprost $0.004 \%$ for 3 months. IOP was assessed at $8 \mathrm{am}, 10 \mathrm{am}$, and $4 \mathrm{pm}$ at week 2 , week 6 , and month 3. Assuming a similar diurnal baseline IOP for the two groups $(25.7 \mathrm{mmHg}$ and $25.9 \mathrm{mmHg}$, respectively, for the PF and the BAK-preserved group), mean IOP reductions across all nine study visits and times ranged from 7.3 to $8.5 \mathrm{mmHg}$ for PF travoprost and from 7.4 to $8.4 \mathrm{mmHg}$ for travoprost preserved with BAK. No significant difference was found between the two formulations.

Patients on treatment with BAK-preserved PGs and with tolerability issues might have some benefits in replacing their therapy with PF travoprost. In a study by Henry et al 691 patients under therapy with latanoprost or bimatoprost with added BAK were shifted, due to intolerance issues, to a therapy with PF travoprost. ${ }^{76}$ Patients were surveyed using the Ocular Surface Disease Index to evaluate ocular surface disease symptoms prior to and 3 months after changing their therapy. PF travoprost demonstrated improved mean Ocular Surface Disease Index scores compared to either latanoprost or bimatoprost $(P<0.001)$ and in $70.2 \%$ of the patients symptoms were reduced in severity by at least one level.

A recent new formulation of travoprost $0.003 \%$, preserved with polyquad, was accepted by the FDA in May 2014. While BAK and other preservatives may have an effect on the ocular surface and influence the risk of glaucoma surgery failure, chronic exposition to active agents certainly has the potential for inducing at least some cellular toxicity and ocular surface changes. $^{70,77}$ This should be taken into account especially for PGs, which are known to be proinflammatory agents. Approval of travoprost $0.003 \%$ by the FDA was granted by a clinical trial of 3 months duration comparing the IOP lowering efficacy of travoprost $0.003 \%$ to travoprost $0.004 \%$ in patients affected by POAG and OHT. ${ }^{78}$ A total of 864 patients were enrolled, with 840 (97\%) completing the study. IOP parameters were compared between treatments at week 2 , week 6, and month 3 for each time-point ( $8 \mathrm{am}, 10 \mathrm{am}$, and $4 \mathrm{pm}$ ). Mean differences in IOP between travoprost $0.003 \%$ and travoprost $0.004 \%$ at the nine assessments ranged from -0.3 to $0.0 \mathrm{mmHg}$, indicating statistical equivalence between treatments. Other studies on travoprost $0.003 \%$ formulation are expected to clarify its role in clinical practice.

\section{Travoprost in pediatric populations}

In December 2014, travoprost $0.004 \%$ was approved by the European Medicines Agency (EMA) for use in pediatric patients, aged 2 months to 18 years, affected by OHT or glaucoma. TheEuropean approval was based ona 12-week, Phase III, multicenter, double-masked, randomized, parallel-group study recruiting 152 patients. ${ }^{79}$ Patients were randomized to treatment with travoprost $0.004 \%$ once-a-day in the evening or treatment with timolol $(0.5 \%$ or $0.25 \%)$ twice daily for 12 weeks. In the travoprost group, the effect on IOP was seen after the 2 nd week of treatment and was consistently maintained throughout the 12 -week study period. No difference was found in IOP reduction between travoprost and timolol. The most frequent adverse events in this pediatric population were conjunctival hyperemia and eyelash growth, similarly to adult patients.

To the best of our knowledge, only one other study, a retrospective study by Yanovitch et al, evaluated efficacy and safety of travoprost $0.004 \%$ in a cohort of 57 pediatric patients (75 eyes), affected by congenital and juvenile glaucoma. ${ }^{80}$ In this study, travoprost was not used as first-line therapy, and was generally added to other glaucoma medications. From the original cohort, only 26 eyes were included in the efficacy analysis, with a mean baseline IOP of $26.3 \pm 6.6 \mathrm{mmHg}$. After 1 month of travoprost treatment, mean IOP was reduced to $21.0 \pm 7.0 \mathrm{mmHg}(P<0.001)$. Fourteen eyes $(54 \%)$ showed a decrease in IOP of $>15 \%$ from baseline after 1 month of treatment. Seventy-five eyes were included in the safety analysis. Travoprost was generally well tolerated and only five eyes discontinued the medication due to ocular adverse events: four because of conjunctival hyperemia and one because of ocular irritation. Eyelash growth was observed in all patients. Even if no definite conclusion can be drawn from this study, due to the retrospective design and the small sample size, travoprost seemed more effective in patients affected by juvenile and aphakic glaucoma, while only onethird of congenital glaucoma patients (4/11) showed an IOP reduction $>15 \%$.

\section{Safety of travoprost}

Ocular hyperemia is a common side effect of PGs, mainly mediated by scleral and conjunctival vasodilation. ${ }^{81}$ The mechanism behind vasodilation is complex and probably involves release of nitric oxide stimulated by $\mathrm{PGs}^{82}$ and response 
from sensory nerves. ${ }^{83}$ Other mediators may be involved, such as calcitonin gene-related peptide and substance $\mathrm{P} .{ }^{84}$

Netland et al found clinically significant changes in ocular hyperemia in $49.5 \%$ of patients treated with travoprost $0.004 \%$, in $27.6 \%$ of patients treated with latanoprost, and in $14.0 \%$ of patients treated with timolol.$^{52}$ However, mean hyperemia score in all the treatments groups was less than 1 on a scale of $0-3$, indicating that, on average, the majority of patients experienced none/trace to mild hyperemia. Hyperemia was evident since the first follow-up visit, at week 2.

Konstas et al found no difference in ocular hyperemia incidence among patients treated with travoprost $0.004 \%$ dosed in the evening or in the morning. ${ }^{45}$ Respectively, hyperemia was encountered in $27 \%$ and in $33 \%$ of patients $(P=0.6)$. In another study, the same authors noted that conjunctival hyperemia was seen twice as often with travoprost (15 patients) as with latanoprost (six patients). ${ }^{59}$

Darker and longer eyelashes are a well-described side effect of PG treatment. Although PG receptors involved in the development and regrowth of the hair follicle have been identified in the outer root sheath of dermal papilla, ${ }^{85,86}$ it is not known whether PGs exert their effects on them. Misdirected growth, resulting in lash ptosis or trichiasis requiring intervention, has been reported.$^{87} \mathrm{~A}$ meta-analysis by Li et al found major risks of eyelash changes in patients treated with travoprost compared to latanoprost (odds ratio: 3.8 , $P<0.001) .{ }^{54}$ However, only two studies were included in the analysis, so results must be interpreted with caution. Eyelash changes are probably a reversible side effect and cessation of the treatment may restore the original condition. ${ }^{88,89}$

Iris darkening is a common side effect of all PGs, but not all eyes are equally at risk. Homogenous green or blue irises are less prone to develop iris darkening than irises with brown patches on blue, green, or gray. ${ }^{90}$ Duration of treatment seems to be a risk factor, and generally iris darkening appears during the first 6-8 months; over $90 \%$ of patients that are going to develop iris darkening will have already done so after 2 years of treatment. ${ }^{91}$ In a 12-month study, Netland et al found iris pigmentation change in $3.1 \%$ of patients under therapy with travoprost $0.004 \%$ and in $5.2 \%$ of patients under therapy with latanoprost. ${ }^{52}$ In a shorter 6-month study comparing travoprost to bimatoprost, Cantor et al found no iris pigmentation change in the cohort of patients randomized to treatment with travoprost $0.004 \%(n=81)$, while one patient developed iris darkening in the bimatoprost group $(n=76) .{ }^{60}$ As iris pigmentation is probably a function of treatment duration, one might expect greater incidence of this side effect in the long-term. Riva et al evaluated safety of travoprost treatment in a 5-year follow-up study, and found a cumulative incidence of iris darkening of $27.7 \%,{ }^{49}$ which is comparable with the $33.4 \%$ rate reported in a 5-year study on latanoprost. ${ }^{91}$

It is not completely understood why PGs induce iris darkening and why this side effect is more common in patients with mixed-color irises than others. Increase in iris pigmentation is probably due to an increase in melanin content within cytoplasm of melanocytes, ${ }^{81,92}$ while an increase in melanocyte proliferation is unlikely. It has been demonstrated that PGF $2 \alpha$ can stimulate, directly or indirectly, melanogenesis, probably though FP receptor action. ${ }^{93-95}$ Although iris pigmentation is thought to be only a cosmetic effect, it should be discussed with patients at the beginning of the therapy, especially in patients with mixed-color irises. Moreover, this side effect should always be evaluated when the patient needs a unilateral therapy, trying to avoid macroscopic differences between eyes (Figure 4).

Few case reports in literature pointed out a potential risk of cystoid macular edema in patients under therapy with

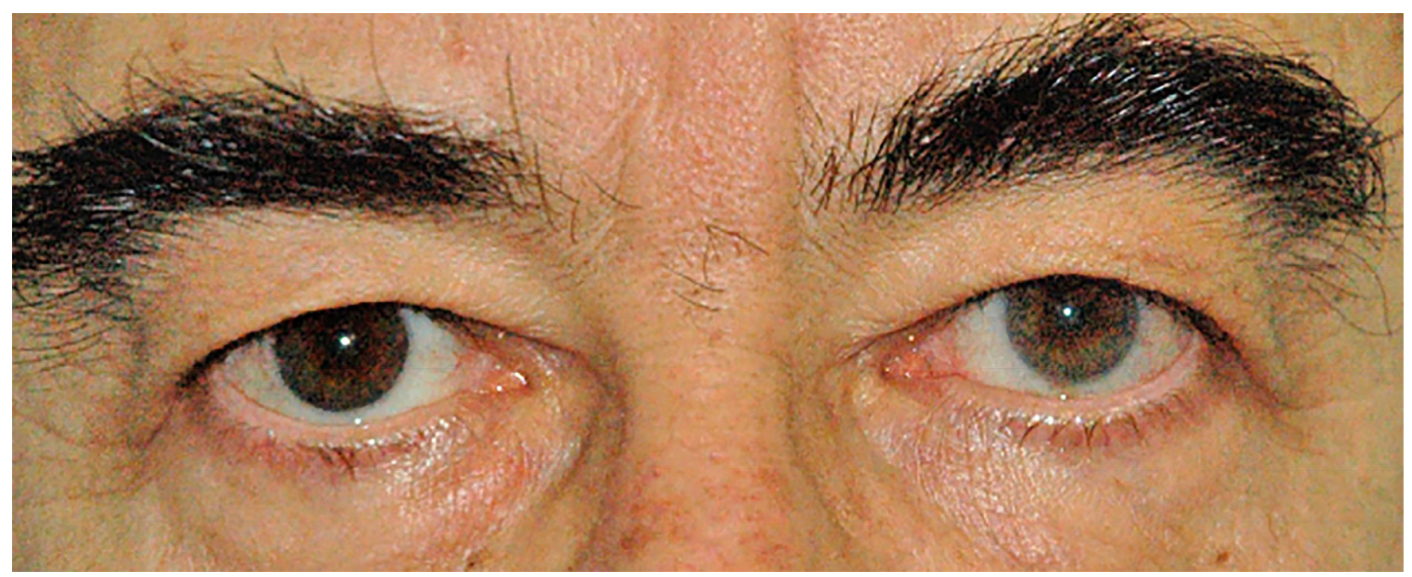

Figure 4 Heterochromia due to unilateral therapy with travoprost in right eye. 
travoprost and other PGs. ${ }^{96-98}$ Proinflammatory properties of PGs may induce a breakdown in the blood-retinal barrier, causing loss of fluids in the macular region. This could be particularly true when a direct communication between the anterior and posterior chamber is present, such as after surgical capsular rupture or in aphakia. However, literature data are lacking. Generally, it seems that the risk of cystoid macular edema is extremely low to nonexistent in low-risk eyes (no intraocular surgeries or uveitis) and that even in high-risk eye the incidence is relatively low. ${ }^{81}$ While therapy with PGs may not be the first-line therapy in aphakic patients or in patients with posterior capsule rupture, no absolute contraindication is actually established.

Anterior uveitis has been linked to travoprost therapy in few case reports. ${ }^{99-103}$ Cessation of travoprost therapy and topical steroids administration are usually sufficient to improve clinical conditions and resolve uveitis. In some cases a rechallenge with travoprost may cause a new onset, demonstrating the causality between therapy and uveitis. ${ }^{103}$ Integrity of the blood-aqueous barrier was studied by Cellini et al in a cohort of 60 glaucoma patients randomized to treatment with travoprost, latanoprost, and bimatoprost. ${ }^{104}$ Anterior chamber flare and cells were evaluated at baseline and after 3 and 6 months of therapy. The authors found a significant increase in cells and flare at the 3-and 6-month visit for all PGs, whereas a slight reduction in cells and flare was noted between 3 and 6 months. Only at the 3-month visit did travoprost induce a higher rate of flare and cells than bimatoprost. Even though a link between travoprost therapy and anterior uveitis may be assumed, it should be kept in mind that uveitis is an extremely rare side effect of this therapy.

\section{Conclusion}

PGs are highly effective in reducing IOP in patients affected by POAG and OHT. Studies show that travoprost reduces IOP on average by $27 \%-30 \%$, with no tachyphylaxis in the long-term. ${ }^{43,44,49}$ Efficacy of travoprost has been demonstrated in the daytime but also in a 24-hour period, with persistency of its pharmacological effect until 84 hours from the last administration. ${ }^{47,48}$ Convenience of one-day dosing and minor side effects make this drug a good choice as first-line therapy in glaucoma patients. Moreover, the combination of travoprost with timolol in an FC can limit side effects due to concomitant administration of the two drugs, and is advisable for patients requiring a greater IOP reduction or at greater risk of glaucoma progression. Future researches are needed to evaluate the role of the new formulation of travoprost $0.003 \%$ in current clinical practice.

\section{Disclosure}

Luciano Quaranta: honoraria or travel reimbursement from Alcon, Allergan, MSD, Thea Farmila, and Bausch and Lomb. Ivano Riva: honoraria or travel reimbursement from Alcon, Allergan, MSD, and Sooft; Andreas Katsanos: travel reimbursement from Alcon and MSD; Anastasios G P Konstas: consultant for Alcon, Allergan, MSD, and Nicox. Irene Floriani and Marco Centofanti report no conflicts of interest in this work.

\section{References}

1. Friedman DS, Wolfs RC, O'Colmain BJ, et al. Prevalence of openangle glaucoma among adults in the United States. Arch Ophthalmol. 2004;122(4):532-538.

2. Thylefors B, Négrel AD. The global impact of glaucoma. Bull World Health Organ. 1994;72(3):323-326.

3. Quigley HA, Broman AT. The number of people with glaucoma worldwide in 2010 and 2020. Br J Ophthalmol. 2006;90(3):262-267.

4. Agarwal R, Gupta SK, Agarwal P, Saxena R, Agrawal SS. Current concepts in the pathophysiology of glaucoma. Indian J Ophthalmol. 2009; 57(4):257-266.

5. Pillunat LE, Stodtmeister R, Marquardt R, Mattern A. Ocular perfusion pressures in different types of glaucoma. Int Ophthalmol. 1989; 13(1-2):37-42.

6. Quaranta L, Manni G, Donato F, Bucci MG. The effect of increased intraocular pressure on pulsatile ocular blood flow in low tension glaucoma. Surv Ophthalmol. 1994;38 Suppl:S177-S181; discussion S182.

7. Quaranta L, Katsanos A, Russo A, Riva I. 24-hour intraocular pressure and ocular perfusion pressure in glaucoma. Surv Ophthalmol. 2013; 58(1):26-41.

8. Grunwald JE, Sinclair SH, Riva CE. Autoregulation of the retinal circulation in response to decrease of intraocular pressure below normal. Invest Ophthalmol Vis Sci. 1982;23(1):124-127.

9. Pillunat LE, Anderson DR, Knighton RW, Joos KM, Feuer WJ. Autoregulation of human optic nerve head circulation in response to increased intraocular pressure. Exp Eye Res. 1997;64(5):737-744.

10. Ojha P, Wiggs JL, Pasquale LR. The genetics of intraocular pressure. Semin Ophthalmol. 2013;28(5-6):301-305.

11. Leske MC, Heijl A, Hyman L, Bengtsson B, Komaroff E. Factors for progression and glaucoma treatment: the Early Manifest Glaucoma Trial. Curr Opin Ophthalmol. 2004;15(2):102-106.

12. Garway-Heath DF, Crabb DP, Bunce C, et al. Latanoprost for openangle glaucoma (UKGTS): a randomised, multicentre, placebocontrolled trial. Lancet. Epub 2014 Dec 18.

13. Rulli E, Biagioli E, Riva I, et al. Efficacy and safety of trabeculectomy vs nonpenetrating surgical procedures: a systematic review and metaanalysis. JAMA Ophthalmol. 2013;131(12):1573-1582.

14. Sharif NA, Kelly CR, Crider JY. Agonist activity of bimatoprost, travoprost, latanoprost, unoprostone isopropyl ester and other prostaglandin analogs at the cloned human ciliary body FP prostaglandin receptor. J Ocul Pharmacol Ther. 2002;18(4):313-324.

15. Sharif NA, Kelly CR, Crider JY. Human trabecular meshwork cell responses induced by bimatoprost, travoprost, unoprostone, and other FP prostaglandin receptor agonist analogues. Invest Ophthalmol Vis Sci. 2003;44(2):715-721.

16. Bean GW, Camras CB. Commercially available prostaglandin analogs for the reduction of intraocular pressure: similarities and differences. Surv Ophthalmol. 2008;53 Suppl 1:S69-S84.

17. Bito LZ, Baroody RA. The ocular pharmacokinetics of eicosanoids and their derivatives. 1. Comparison of ocular eicosanoid penetration and distribution following the topical application of PGF2 alpha, PGF2 alpha-1-methyl ester, and PGF2 alpha-1-isopropyl ester. Exp Eye Res. 1987;44(2):217-226. 
18. Villumsen J, Alm A, Söderström M. Prostaglandin F2 alpha-isopropylester eye drops: effect on intraocular pressure in open-angle glaucoma. $\mathrm{Br}$ J Ophthalmol. 1989;73(12):975-979.

19. Hellberg MR, Sallee VL, McLaughlin MA, et al. Preclinical efficacy of travoprost, a potent and selective FP prostaglandin receptor agonist. J Ocul Pharmacol Ther. 2001;17(5):421-432.

20. Denis P, Covert D, Realini A. Travoprost in the management of openangle glaucoma and ocular hypertension. Clin Ophthalmol. 2007; 1(1):11-24.

21. McCue BA, Cason MM, Curtis MA, Faulkner RD, Dahlin DC. Determination of travoprost and travoprost free acid in human plasma by electrospray HPLC/MS/MS. J Pharm Biomed Anal. 2002;28(2):199-208.

22. Toris CB, Gabelt BT, Kaufman PL. Update on the mechanism of action of topical prostaglandins for intraocular pressure reduction. Surv Ophthalmol. 2008;53 Suppl 1:S107-S120.

23. Toris CB, Zhan GL, Camras CB, McLaughlin MA. Effects of travoprost on aqueous humor dynamics in monkeys. J Glaucoma. 2005; 14(1):70-73.

24. Toris CB, Zhan G, Fan S, et al. Effects of travoprost on aqueous humor dynamics in patients with elevated intraocular pressure. J Glaucoma. 2007;16(2):189-195.

25. Schlötzer-Schrehardt U, Zenkel M, Nüsing RM. Expression and localization of FP and EP prostanoid receptor subtypes in human ocular tissues. Invest Ophthalmol Vis Sci. 2002;43(5):1475-1487.

26. Ocklind A. Effect of latanoprost on the extracellular matrix of the ciliary muscle. A study on cultured cells and tissue sections. Exp Eye Res. 1998;67(2):179-191.

27. Sagara T, Gaton DD, Lindsey JD, Gabelt BT, Kaufman PL, Weinreb RN. Topical prostaglandin F2alpha treatment reduces collagen types I, III and IV in the monkey uveoscleral outflow pathway. Arch Ophthalmol. 1999;117(6):794-801.

28. Poyer JF, Millar C, Kaufman PL. Prostaglandin F2 alpha effects on isolated rhesus monkey ciliary muscle. Invest Ophthalmol Vis Sci. 1995 36(12):2461-2465.

29. Alphen GW, Wilhelm PB, Elsenfeld PW. The effect of prostaglandins on the isolated internal muscles of the mammalian eye, including man. Doc Ophthalmol. 1977;42(2):397-415.

30. Stjernschantz J, Selén G, Ocklind A, Resul B. Effects of latanoprost and related prostaglandin analogues. In: Alm, Weinreb RN, editors. Uveoscleral Outflow. Biology and Clinical Aspects. London, UK: Mosby International Limited; 1998:57-72.

31. Gaton DD, Sagara T, Lindsey JD, Gabelt BT, Kaufman PL, Weinreb RN. Increased matrix metalloproteinases 1, 2, and 3 in the monkey uveoscleral outflow pathway after topical prostaglandin F(2 alpha)-isopropyl ester treatment. Arch Ophthalmol. 2001;119(8):1165-1170.

32. Husain S, Jafri F, Crosson CE. Acute effects of PGF2alpha on MMP-2 secretion from human ciliary muscle cells: a PKC- and ERK-dependent process. Invest Ophthalmol Vis Sci. 2005;46(5):1706-1713.

33. Lutjen-Drecoll E, Tamm E. Morphological study of the anterior segment of cynomolgus monkey eyes following treatment with prostaglandin F2 alpha. Exp Eye Res. 1988;47(5):761-769.

34. Nilsson SF, Drecoll E, Lütjen-Drecoll E, et al. The prostanoid EP2 receptor agonist butaprost increases uveoscleral outflow in the cynomolgus monkey. Invest Ophthalmol Vis Sci. 2006;47(9): 4042-4049.

35. Richter M, Krauss AH, Woodward DF, Lutjen-Drecoll E. Morphological changes in the anterior eye segment after long-term treatment with different receptor selective prostaglandin agonists and a prostamide. Invest Ophthalmol Vis Sci. 2003;44(10):4419-4426.

36. Krebs W, Krebs IP. Ultrastructural evidence for lymphatic capillaries in the primate choroid. Arch Ophthalmol. 1988;106(11):1615-1616.

37. Alexander JP, Samples JR, Van Buskirk EM, Acott TS. Expression of matrix metalloproteinases and inhibitor by human trabecular meshwork. Invest Ophthalmol Vis Sci. 1991;32(1):172-180.

38. Bradley JM, Vranka J, Colvis CM, et al. Effect of matrix metalloproteinases activity on outflow in perfused human organ culture. Invest Ophthalmol Vis Sci. 1998;39(13):2649-2658.
39. Vaajanen A, Vapaatalo H, Oksala O. A modified in vitro method for aqueous humor outflow studies in enucleated porcine eyes. $J$ Ocul Pharmacol Ther. 2007;23(2):124-131.

40. Bahler CK, Howell KG, Hann CR, Fautsch MP, Johnson DH. Prostaglandins increase trabecular meshwork outflow facility in cultured human anterior segments. Am J Ophthalmol. 2008;145(1):114-119.

41. Zhao X, Pearson KE, Stephan DA, Russell P. Effects of prostaglandin analogues on human ciliary muscle and trabecular meshwork cells. Invest Ophthalmol Vis Sci. 2003;44(5):1945-1952.

42. Eisenberg DL, Toris CB, Camras CB. Bimatoprost and travoprost: a review of recent studies of two new glaucoma drugs. Surv Ophthalmol. 2002;47 Suppl 1:S105-S115.

43. Holmstrom S, Buchholz P, Walt J, Wickstrøm J, Aagren M. Analytic review of bimatoprost, latanoprost and travoprost in primary open angle glaucoma. Curr Med Res Opin. 2005;21(11):1875-1883.

44. van der Valk R, Webers CA, Schouten JS, Zeegers MP, Hendrikse F, Prins $\mathrm{MH}$. Intraocular pressure-lowering effects of all commonly used glaucoma drugs: a meta-analysis of randomized clinical trials. Ophthalmology. 2005;112(7):1177-1185

45. Konstas AG, Mikropoulos D, Kaltsos K, Jenkins JN, Stewart WC. 24-hour intraocular pressure control obtained with evening- versus morning-dosed travoprost in primary open-angle glaucoma. Ophthalmology. 2006;113(3):446-450.

46. Konstas AG, Mikropoulos D, Haidich AB, Ntampos KS, Stewart WC. Twenty-four-hour intraocular pressure control with the travoprost/ timolol maleate fixed combination compared with travoprost when both are dosed in the evening in primary open-angle glaucoma. $\mathrm{Br}$ J Ophthalmol. 2009;93(4):481-485.

47. Stewart WC, Konstas AG, Nelson LA, Kruft B. Meta-analysis of 24-hour intraocular pressure studies evaluating the efficacy of glaucoma medicines. Ophthalmology. 2008;115(7):1117-1122.e1.

48. Dubiner HB, Sircy MD, Landry T, et al. Comparison of the diurnal ocular hypotensive efficacy of travoprost and latanoprost over a 44-hour period in patients with elevated intraocular pressure. Clin Ther. 2004;26(1):84-91.

49. Riva I, Katsanos A, Floriani I, et al. Long-term 24-hour intraocular pressure control with travoprost monotherapy in patients with primary open-angle glaucoma. J Glaucoma. 2014;23(8):535-540.

50. Goldberg I, Cunha-Vaz J, Jakobsen JE, et al. Comparison of topical travoprost eye drops given once daily and timolol $0.5 \%$ given twice daily in patients with open-angle glaucoma or ocular hypertension. J Glaucoma. 2001;10(5):414-422.

51. Fellman RL, Sullivan EK, Ratliff M, et al. Comparison of travoprost $0.0015 \%$ and $0.004 \%$ with timolol $0.5 \%$ in patients with elevated intraocular pressure: a 6-month, masked, multicenter trial. Ophthalmology. 2002;109(5):998-1008.

52. Netland PA, Landry T, Sullivan EK, et al. Travoprost compared with latanoprost and timolol in patients with open-angle glaucoma or ocular hypertension. Am J Ophthalmol. 2001;132(4):472-484.

53. Barnebey HS, Orengo-Nania S, Flowers BE, et al. The safety and efficacy of travoprost $0.004 \% /$ timolol $0.5 \%$ fixed combination ophthalmic solution. Am J Ophthalmol. 2005;140(1):1-7.

54. Li N, Chen XM, Zhou Y, Wei ML, Yao X. Travoprost compared with other prostaglandin analogues or timolol in patients with open-angle glaucoma or ocular hypertension: meta-analysis of randomized controlled trials. Clin Experiment Ophthalmol. 2006;34(8):755-764.

55. Holló G, Thelen U, Teus MA, et al. Long-term outcomes of prostaglandin analog versus timolol maleate in ocular hypertensive or primary open-angle glaucoma patients in Europe. J Ocul Pharmacol Ther. 2011;27(5):493-498.

56. Parrish RK, Palmberg P, Sheu WP, XLT Study Group. A comparison of latanoprost, bimatoprost, and travoprost in patients with elevated intraocular pressure: a 12-week, randomized, masked-evaluator multicenter study. Am J Ophthalmol. 2003;135(5):688-703.

57. Noecker RJ, Earl ML, Mundorf T, Peace J, Williams RD. Bimatoprost $0.03 \%$ versus travoprost $0.004 \%$ in black Americans with glaucoma or ocular hypertension. Adv Ther. 2003;20(2):121-128. 
58. Cardascia N, Vetrugno M, Trabucco T, Cantatore F, Sborgia C. Effects of travoprost eye drops on intraocular pressure and pulsatile ocular blood flow: a 180-day, randomized, double-masked comparison with latanoprost eye drops in patients with open-angle glaucoma. Curr Ther Res Clin Exp. 2003;64(7):389-400.

59. Konstas AG, Kozobolis VP, Katsimpris IE, et al. Efficacy and safety of latanoprost versus travoprost in exfoliative glaucoma patients. Ophthalmology. 2007;114(4):653-657.

60. Cantor LB, Hoop J, Morgan L, Wudunn D, Catoira Y, BimatoprostTravoprost Study Group. Intraocular pressure-lowering efficacy of bimatoprost $0.03 \%$ and travoprost $0.004 \%$ in patients with glaucoma or ocular hypertension. Br J Ophthalmol. 2006;90(11): 1370-1373.

61. Kass MA, Heuer DK, Higginbotham EJ, et al. The Ocular Hypertension Treatment Study: a randomized trial determines that topical ocular hypotensive medication delays or prevents the onset of primary openangle glaucoma. Arch Ophthalmol. 2002;120(6):701-713; discussion 829-830.

62. Hughes BA, Bacharach J, Craven ER, et al. A three-month, multicenter, double-masked study of the safety and efficacy of travoprost $0.004 \%$ / timolol $0.5 \%$ ophthalmic solution compared to travoprost $0.004 \%$ ophthalmic solution and timolol $0.5 \%$ dosed concomitantly in subjects with open angle glaucoma or ocular hypertension. J Glaucoma. 2005;14(5):392-399.

63. Schuman JS, Katz GJ, Lewis RA, et al. Efficacy and safety of a fixed combination of travoprost $0.004 \% /$ timolol $0.5 \%$ ophthalmic solution once daily for open-angle glaucoma or ocular hypertension. Am J Ophthalmol. 2005;140(2):242-250.

64. Quaranta L, Biagioli E, Riva I, et al. Prostaglandin analogs and timololfixed versus unfixed combinations or monotherapy for open-angle glaucoma: a systematic review and meta-analysis. J Ocul Pharmacol Ther. 2013;29(4):382-389.

65. Noecker R. Effects of common ophthalmic preservatives on ocular health. Adv Ther. 2001;18(5):205-215.

66. Baudouin C, Liang H, Hamard P, et al. The ocular surface of glaucoma patients treated over the long term expresses inflammatory markers related to both T-helper 1 and T-helper 2 pathways. Ophthalmology. 2008;115(1):109-115.

67. Broadway DC, Grierson I, O’Brien C, Hitchings RA. Adverse effects of topical antiglaucoma medication. I. The conjunctival cell profile. Arch Ophthalmol. 1994;112(11):1437-1445.

68. Burstein NL. Corneal cytotoxicity of topically applied drugs, vehicles and preservatives. Surv Ophthalmol. 1980;25(1):15-30.

69. Ishibashi T, Yokoi N, Kinoshita S. Comparison of the short-term effects on the human corneal surface of topical timolol maleate with and without benzalkonium chloride. J Glaucoma. 2003;12(6):486-490.

70. Boimer C, Birt CM. Preservative exposure and surgical outcomes in glaucoma patients: The PESO study. J Glaucoma. 2013;22(9): 730-735.

71. Brignole-Baudouin F, Riancho L, Liang H, Baudouin C. Comparative in vitro toxicology study of travoprost polyquad-preserved, travoprost BAK-preserved, and latanoprost BAK-preserved ophthalmic solutions on human conjunctival epithelial cells. Curr Eye Res. 2011; 36(11):979-988.

72. Liang H, Brignole-Baudouin F, Riancho L, Baudouin C. Reduced in vivo ocular surface toxicity with polyquad-preserved travoprost versus benzalkonium-preserved travoprost or latanoprost ophthalmic solutions. Ophthalmic Res. 2012;48(2):89-101.

73. Choy CK, Cho P, Boost MV. Cytotoxicity and effects on metabolism of contact lens care solutions on human corneal epithelium cells. Clin Exp Optom. 2012;95(2):198-206.

74. Choy CK, Cho P, Boost MV, Benzie IF. Do multipurpose solutions damage porcine corneal epithelial cells? Optom Vis Sci. 2009;86(5): E447-E453.

75. Lewis RA, Katz GJ, Weiss MJ, et al. Travoprost $0.004 \%$ with and without benzalkonium chloride: a comparison of safety and efficacy. J Glaucoma. 2007;16(1):98-103.
76. Henry JC, Peace JH, Stewart JA, Stewart WC. Efficacy, safety, and improved tolerability of travoprost BAK-free ophthalmic solution compared with prior prostaglandin therapy. Clin Ophthalmol. 2008;2(3):613-621.

77. Fukuchi T, Wakai K, Suda K, et al. Incidence, severity and factors related to drug-induced keratoepitheliopathy with glaucoma medications. Clin Ophthalmol. 2010;4:203-209.

78. Alcon Research. Travoprost 3-Month Safety and Efficacy Study. Available from: https://clinicaltrials.gov/show/NCT01453855. NLM Identifier: NCT01453855. Accessed January 17, 2014.

79. Alcon Research. Study of Travoprost Ophthalmic Solution, 0.004\% Compared to Timolol ( $0.5 \%$ or $0.25 \%)$ in Pediatric Glaucoma Patients. Available from: https://clinicaltrials.gov/show/NCT01652664. NLM Identifier: NCT01652664. Accessed January 17, 2014.

80. Yanovitch TL, Enyedi LB, Schotthoeffer EO, Freedman SF. Travoprost in children: adverse effects and intraocular pressure response. JAAPOS. 2009;13(1):91-93.

81. Alm A, Grierson I, Shields MB. Side effects associated with prostaglandin analog therapy. Surv Ophthalmol. 2008;53 Suppl 1:S93-S105.

82. Astin M, Stjernschantz J, Selén G. Role of nitric oxide in PGF2 alphainduced ocular hyperemia. Exp Eye Res. 1994;59(4):401-407.

83. Astin M, Stjernschantz J. Mediation of prostaglandin $\mathrm{f} 2$ alpha-induced ocular surface hyperemia by sensory nerves in rabbits. Curr Eye Res. 1997;16(9):886-890.

84. Astin M, Stjernschantz J. Mechanism of prostaglandin E2-, F2alpha- and latanoprost acid-induced relaxation of submental veins. Eur J Pharmacol. 1997;340(2-3):195-201.

85. Tosti A, Pazzaglia M, Voudouris S, Tosti G. Hypertrichosis of the eyelashes caused by bimatoprost. J Am Acad Dermatol. 2004; 51(5 Suppl):S149-S150.

86. Colombe L, Michelet JF, Bernard BA. Prostanoid receptors in anagen human hair follicles. Exp Dermatol. 2008;17(1):63-72.

87. Bearden W, Anderson R. Trichiasis associated with prostaglandin analog use. Ophthal Plast Reconstr Surg. 2004;20(4):320-322.

88. Hart J, Shafranov G. Hypertrichosis of vellus hairs of the malar region after unilateral treatment with bimatoprost. Am J Ophthalmol. 2004;137(4):756-757.

89. O'Toole L, Cahill M, O'Brien C. Eyelid hypertrichosis associated with latanoprost is reversible. Eur J Ophthalmol. 2001;11(4):377-379.

90. Wistrand PJ, Stjernschantz J, Olsson K. The incidence and time-course of latanoprost-induced iridial pigmentation as a function of eye color. Surv Ophthalmol. 1997;41 Suppl 2:S129-S138.

91. Alm A, Schoenfelder J, McDermott J. A 5-year, multicenter, openlabel, safety study of adjunctive latanoprost therapy for glaucoma. Arch Ophthalmol. 2004;122(7):957-965.

92. Imesch PD, Bindley CD, Khademian Z, et al. Melanocytes and iris color. Electron microscopic findings. Arch Ophthalmol. 1996;114(4): 443-447.

93. Prota G, Vincensi MR, Napolitano A, Selen G, Stjernschantz J. Latanoprost stimulates eumelanogenesis in iridial melanocytes of cynomolgus monkeys. Pigment Cell Res. 2000;13(3):147-150.

94. Lindquist NG, Larsson BS, Stjernschantz J. Increased pigmentation of iridial melanocytes in primates induced by a prostaglandin analogue. Exp Eye Res. 1999;69(4):431-436.

95. Smith-Thomas L, Moustafa M, Spada CS, et al. Latanoprost-induced pigmentation in human iridial melanocytes is fibroblast dependent. Exp Eye Res. 2004;78(5):973-985.

96. Del Hierro Zarzuelo A, Martínez de la Casa JM, García Feijoó J, Castillo Gómez A, Méndez Hernández C, García Sánchez J. [Cystoid macular edema induced by travoprost]. Arch Soc Esp Oftalmol. 2004;79(6):295-297. Spanish.

97. Arcieri ES, Santana A, Rocha FN, Guapo GL, Costa VP. Blood-aqueous barrier changes after the use of prostaglandin analogues in patients with pseudophakia and aphakia: a 6-month randomized trial. Arch Ophthalmol. 2005;123(2):186-192.

98. Esquenazi S. Cystoid macular edema in a pseudophakic patient after switching from latanoprost to BAK-free travoprost. J Ocul Pharmacol Ther. 2007;23(6):567-570. 
99. Faulkner WJ, Burk SE. Acute anterior uveitis and corneal edema associated with travoprost. Arch Ophthalmol. 2003;121(7):1054-1055.

100. Kumarasamy M, Desai SP. Anterior uveitis is associated with travoprost. BMJ. 2004;329(7459):205.

101. Suominen S, Välimäki J. Bilateral anterior uveitis associated with travoprost. Acta Ophthalmol Scand. 2006;84(2):275-276.

102. Aydin S, Ozcura F. Corneal oedema and acute anterior uveitis after two doses of travoprost. Acta Ophthalmol Scand. 2007;85(6):693-694.
103. Chiam P. Travoprost induced granulomatous anterior uveitis. Case Rep Ophthalmol Med. 2011;2011:507073.

104. Cellini M, Caramazza R, Bonsanto D, Bernabini B, Campos EC. Prostaglandin analogs and blood-aqueous barrier integrity: a flare cell meter study. Ophthalmologica. 2004;218(5):312-317.

\section{Publish your work in this journal}

Clinical Ophthalmology is an international, peer-reviewed journal covering all subspecialties within ophthalmology. Key topics include: Optometry; Visual science; Pharmacology and drug therapy in eye diseases; Basic Sciences; Primary and Secondary eye care; Patien Safety and Quality of Care Improvements. This journal is indexed on

Submit your manuscript here: http://www.dovepress.com/clinical-ophthalmology-journal

\section{Dovepress}

PubMed Central and CAS, and is the official journal of The Society of Clinical Ophthalmology (SCO). The manuscript management system is completely online and includes a very quick and fair peer-review system, which is all easy to use. Visit http://www.dovepress.com/ testimonials.php to read real quotes from published authors. 